\title{
Chemometric Study of Trace Elements in Hard Coals of the Upper Silesian Coal Basin, Poland
}

\author{
Adam Smoliński, ${ }^{1}$ Przemysław Rompalski, ${ }^{2}$ Krzysztof Cybulski, $^{3}$ \\ Jarosław Chećko, ${ }^{4}$ and Natalia Howaniec ${ }^{1}$ \\ ${ }^{1}$ Department of Energy Saving and Air Protection, Central Mining Institute, Plac Gwarków 1, \\ 40-166 Katowice, Poland \\ ${ }^{2}$ Department of Solid Fuels Quality Assessment, Central Mining Institute, Plac Gwarków 1, 40-166 Katowice, Poland \\ ${ }^{3}$ Central Mining Institute, Experimental Mine "Barbara", Podleska Street 72, 43-190 Mikołów, Poland \\ ${ }^{4}$ Department of Geology and Geophysics, Central Mining Institute, Plac Gwarków 1, 40-166 Katowice, Poland
}

Correspondence should be addressed to Adam Smoliński; smolin@gig.katowice.pl

Received 22 January 2014; Revised 9 April 2014; Accepted 23 April 2014; Published 22 May 2014

Academic Editor: Dušanka Milojković-Opsenica

Copyright ( 2014 Adam Smoliński et al. This is an open access article distributed under the Creative Commons Attribution License, which permits unrestricted use, distribution, and reproduction in any medium, provided the original work is properly cited.

\begin{abstract}
The objective of the study was the analysis of trace elements contents in coals of the Upper Silesian Coal Basin (USCB), which may pose a potential threat to the environment when emitted from coal processing systems. Productive carbon overburden in central and southern zones of the USCB is composed mostly of insulating tertiary formations of a thickness from a few $\mathrm{m}$ to $1,100 \mathrm{~m}$, and is represented by Miocene and Pliocene formations. In the data study the geological conditions of the coal seams of particular zones of the USCB were taken into account and the hierarchical clustering analysis was applied, which enabled the exploration of the dissimilarities between coal samples of various zones of the USCB in terms of basic physical and chemical parameters and trace elements contents. Coals of the northern and eastern zones of the USCB are characterized by high average Hg and low average Ba, $\mathrm{Cr}$, and $\mathrm{Ni}$ contents, whereas coals of southern and western zones are unique due to high average concentrations of $\mathrm{Ba}, \mathrm{Co}, \mathrm{Cu}, \mathrm{Ni}$, and V. Coals of the central part of the USCB are characterized by the highest average concentration of Mn and the lowest average concentrations of $\mathrm{As}, \mathrm{Cd}, \mathrm{Pb}, \mathrm{V}$, and $\mathrm{Zn}$.
\end{abstract}

\section{Introduction}

Coal is considered to be the dominant fossil fuel in terms of the world energy supplies security. Over $90 \%$ of Polish and $40 \%$ of the world power generation is based on coal [1]. Poland is the eighth world coal producer ( $71.34 \mathrm{mln} \mathrm{Mg} /$ year of hard coal and $64.30 \mathrm{mln} \mathrm{Mg} /$ year of lignite in 2012) [2]. The processes of thermochemical conversion of coal are, however, the sources of contaminants, such as carbon dioxide, nitrogen oxides, sulfur oxides, dust, and trace elements [3-5]. Clean Coal Technologies (CCT) are developed to mitigate the negative environmental impact of coal processing in the energy sector. Emissions of hazardous elements from coal combustion process have been extensively studied in recent years [6-13]. Recognition of the modes of occurrence of trace elements in coal is crucial in understanding their chemical, thermal, and environmental behaviors in the processes of coal treatment and thermochemical conversion [14, 15]. The information on geochemical characteristics of coal seam as well as the chemical and elemental composition is fundamental for efficient utilization of coal and reduction of its negative environmental impact [16]. The behavior of trace elements depends on coal types $[17,18]$ and on the operating parameters of the combustion process. High combustion temperatures and reducing atmosphere promote the release of trace metals [19].

The main objective of the study was to investigate the differences between coals provided by coal mines located in various zones of the Upper Silesian Coal Basin (USCB), the largest hard coal basin in Poland. The relationships between the basic physical and chemical parameters and trace elements concentrations in hard coal samples taking 


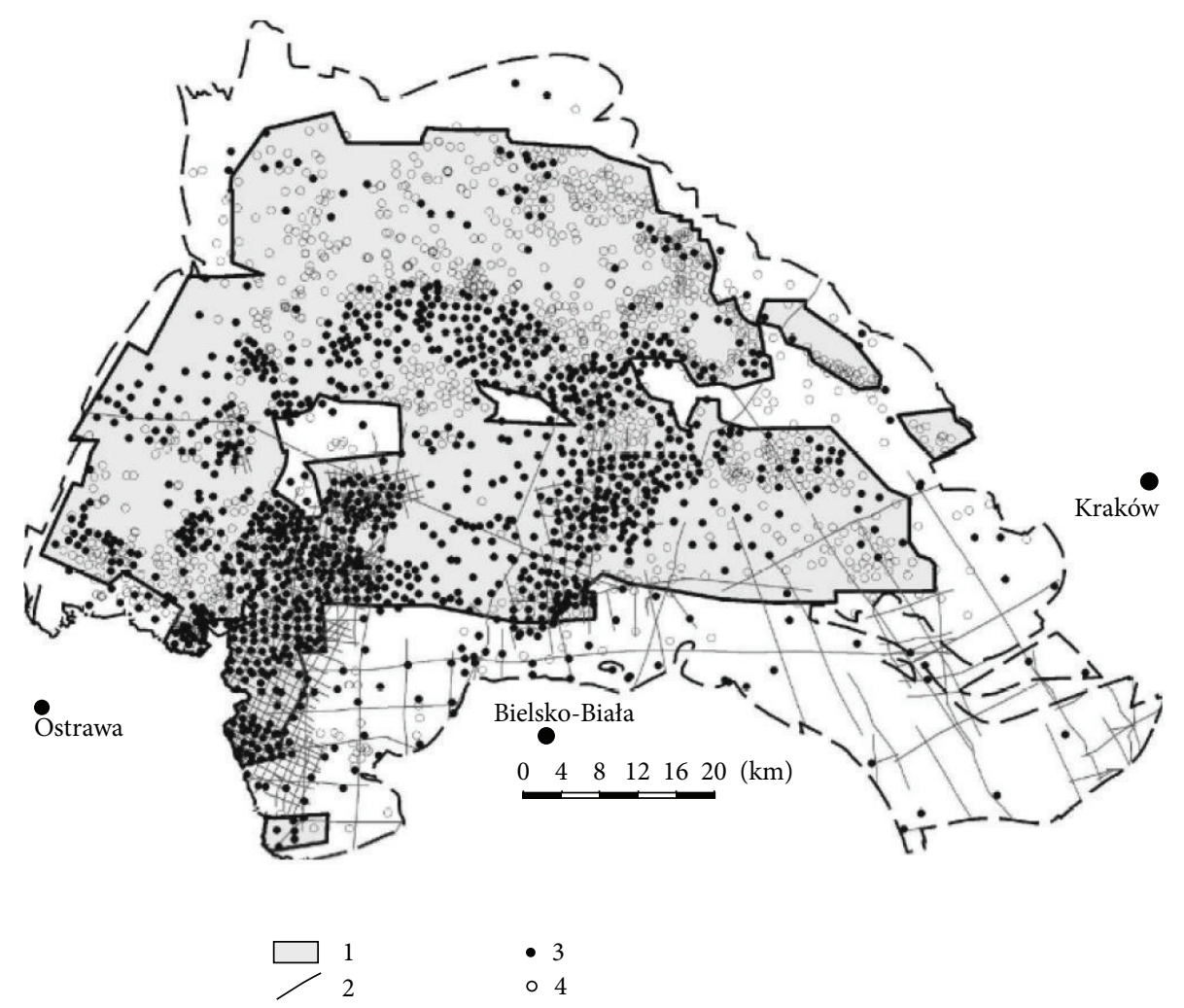

FIGURE 1: Geological exploration of the Upper Silesian Coal basin 1-documented area, 2-seismic profiles, 3-wells of the depth of at least $1,000 \mathrm{~m}$, and 4-wells of a depth of 500-1,000 $\mathrm{m} \mathrm{[28].}$

into account the geological conditions of the USCB were also investigated. For that purpose the hierarchical clustering analysis (HCA) [20-26] was applied complemented with a color map of the studied data set, which allowed more indepth interpretation of the clustering tendency between hard coal samples of various zones of the Upper Silesian Coal Basin.

\section{Geological Settings}

The Upper Silesian Coal Basin is located on the area of Silesian voivodeship and the eastern part of Malopolska voivodeship. Productive carbon overburden in central and southern zones of the USCB is composed mostly of insulating tertiary formations of thickness from a few $m$ to 1,100 $\mathrm{m}$ [27]. It is represented by Miocene and, on a small area, Pliocene formations. Mining has been started here in the mid-17th century. Nowadays, there are 120 explored and documented hard coal deposits in the USCB, including 46 deposits in operation in 32 coal mines, 34 abandoned deposits, and 40 undeveloped deposits.

The total documented area of the USCB is $3295 \mathrm{~km}^{2}$. The operated coal deposits cover $1,030 \mathrm{~km}^{2}$ (approximately $18 \%$ of the USCB area) and depleted or abandoned deposits: $706 \mathrm{~km}^{2}$ (approximately 12\%). Most of the deposits in operation or abandoned are located in the northern and western parts of the basin. The remaining, undocumented areas of the basin cover southern, eastern, and to a less extent, the northern parts [28]. This area is less geologically explored than the deposits in operation (Figure 1).

The USCB is surrounded by a range of Upper Carboniferous coal-bearing formations and partially by fault lines. To the west it is limited by Lower Carboniferous folded flysch formations.

The north-eastern border is buried under Permian and Triassic formations. Below the Carboniferous formations there are Lower Paleozoic formations, covered with Devonian and Lower Carbon limestone formations (Carboniferous limestone). The south, erosion border, goes under the Carpathian flysch thrust. Here, the metamorphic Precambrian formations may be found, and over them, the Cambrian and Devonian formations. The Carboniferous roof is located here at the depth of 2,000-3,000 m.

The base of the USCB constitutes Precambrian, Cambrian, Devonian, and, partially, younger Carboniferous rocks [27].

The structure of productive Carboniferous formations in the basin is asymmetric. The Carboniferous series is characterized by a dual structure. The lower part, Paralic series, is placed on marine sediments. The upper part, continental deposits of the Upper Silesian sandstone series, mudstone series, and Cracow sandstone series are placed on paralic hiatal surface.

Paralic series are classified to Namur. It is composed of clastic sediments composed mainly of fine- and mediumgrained sandstones $(20-50 \%$ of the series) and biogenic 


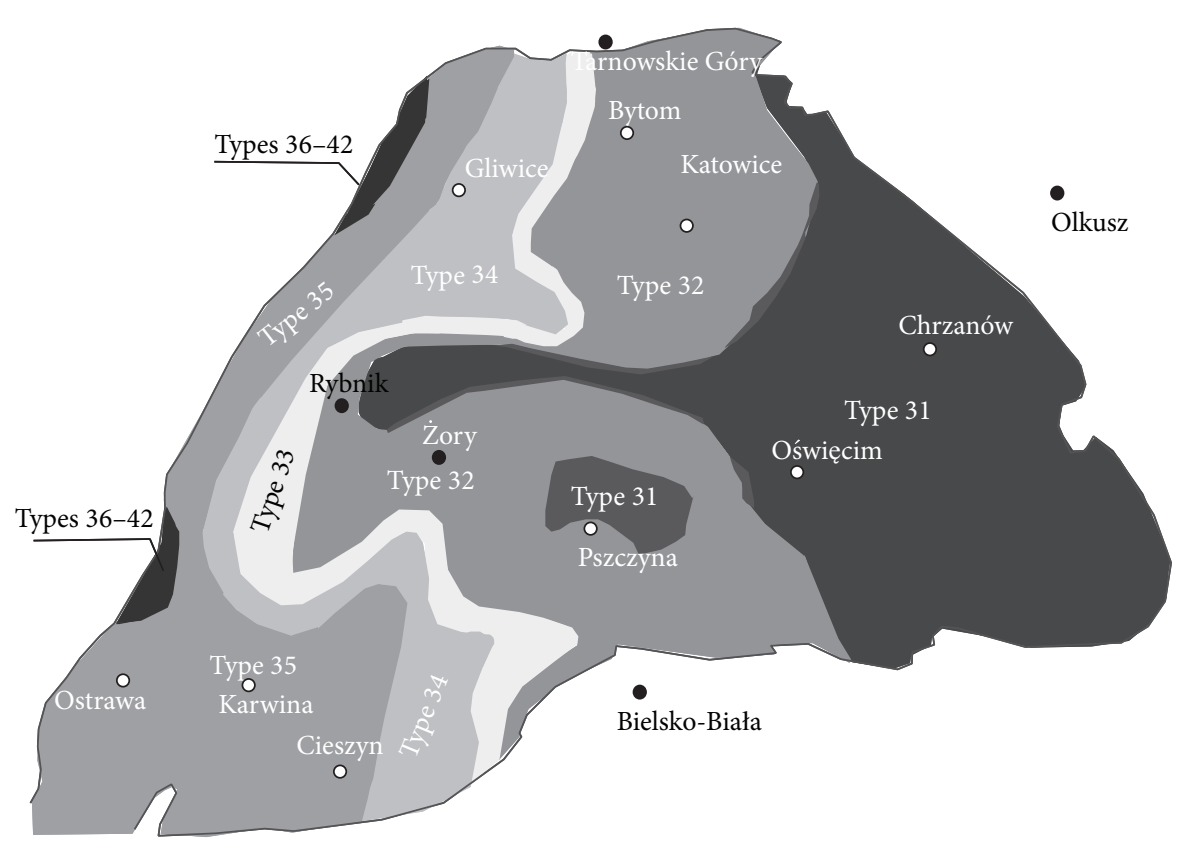

FIgURE 2: Distribution of coal types on USCB Carboniferous roof [33].

sediments (3-4\%). The thickness of paralic series in the eastern part of the USCB is $200 \mathrm{~m}$, and in the western part almost 3,800 m. 110 coal deposits of a thickness of $1-1.5 \mathrm{~m}$ were distinguished in the paralic series profile.

The USCB sandstone series is the first series of so called continental deposits of productive Carboniferous rocks. Here, mainly sandstones, conglomerates, thick coal layers and also fine-grained sandstones and mudstones can be found. Coarse clastic deposits constitute up to 70-90\% of the profile. There are approximately 60 coal deposits in the Upper Silesian sandstone series of the thickness of 4-8 $\mathrm{m}$ [27]. The highest thickness value is reported for coal deposit no. 510, named Reden.

The maximum thickness of the mudstone series in the western part of the basin is up to $2,000 \mathrm{~m}$ and it is reduced to $150 \mathrm{~m}$ in the eastern part. This is the dominant series among the continental productive Carboniferous formations in terms of the area of fine-grain formations: mudstone, mudstone with sandstone, and rarely claystone. Sandstones, mostly fine-grained, constitute only $15-25 \%$ of the profile thickness. There are also numerous thin and variable coal layers of the thickness rarely exceeding $1.5 \mathrm{~m}$. The total of 160 coal layers was determined in the series, of which 70 are of economic importance. The total share of coal in the series profile is $5-7 \%$. It is classified to Westphalian A and lower Westphalian B strata.

Cracow sandstone series is the youngest formation of productive Carboniferous. It is characterized by homogenous structure and is composed mostly of coarse-grained sediments (approximately $70 \%$ of the profile, locally up to $90 \%$ ) of coarse- and medium-grained sandstone of large thickness, separated with intervals of fine-grained sediments, among which coal seams are located. The maximum thickness of the series is 1,140 $\mathrm{m}$ in the Libiaż area. The area of this series is the easternmost and is classified to Westphalian B-D. Coal layers are sparse but of considerable thickness, even of 6-7 $\mathrm{m}$. In the profile 40 coal layers were distinguished, of which 20 were of economic importance.

There are horizontal and vertical variations in coal types in the USCB [29], depending mainly on a coal seam depth and location within the USCB area. Steam coals of types 3133 (according to the Polish Standard PN-82/G-97002) can be found on a considerable area of the basin (Figure 2). In the main basin and on the area between Oświęcim and Rybnik these types of coal are deposited at a depth below 1,000 m. The average ash content is $13 \%$ and in coal seams of particular series it varies between 11 and $16 \%$. The average total sulfur content is between 0.59 and $2.3 \%$. Cocking coals of types 34-35 are located in the south-western part of the USCB (Figure 2). Coal types 36-42 are rare and are situated in the western part of the USCB.

The documented balance resources of hard coal in Poland are estimated to be on the level of 48,225 million $\mathrm{Mg}$ (see Table 1). Polish hard coal deposits belong to the Carboniferous Euro-American province, which is represented in Europe by the belts of paralic and limnic basins [2]. Coal resources are located in three basins: Upper Silesian Coal Basin (USCB), Lublin Coal Basin (LCB), and Lower Silesian Coal Basin (LSCB). The USCB is the largest coal basin in Poland with the area of $5,600 \mathrm{~km}^{2}$ and over $80.2 \%$ of total domestic hard coal deposits. It may be divided into five zones: the northern, southern, eastern, western, and central. The LCB covers an area of $9,100 \mathrm{~km}^{2}$ with $20.9 \%$ of the total domestic hard coal deposits. The resources of the LSCB, estimated to be of approximately 359 million $\mathrm{Mg}$, are located on the area of $350 \mathrm{~km}^{2}$ and have been abandoned for technical and economic reasons. 
TABLE 1: Characteristics of hard coal resources in Poland in 2012 [2].

\begin{tabular}{|c|c|c|c|c|}
\hline & \multirow{2}{*}{ No. of deposits } & \multicolumn{2}{|c|}{ Geological resources [mln $\mathrm{Mg}]$} & \multirow{2}{*}{ Industria } \\
\hline & & Balanced & Off balance & \\
\hline Total & 146 & 48,225 & 18,302 & 4,210 \\
\hline \multicolumn{5}{|c|}{ of which resources of exploited deposits: } \\
\hline Operating plants & 51 & 19,130 & 6,507 & 1,178 \\
\hline \multicolumn{5}{|c|}{ of which resources of off balance deposits: } \\
\hline Total & 52 & 25,139 & 11,173 & - \\
\hline Deposits explored & 34 & 11,423 & 3,619 & - \\
\hline Deposits preexplored & 18 & 13,716 & 7,553 & - \\
\hline \multicolumn{5}{|c|}{ of which resources of abandoned deposits: } \\
\hline Total & 43 & 3,955 & 621 & - \\
\hline
\end{tabular}

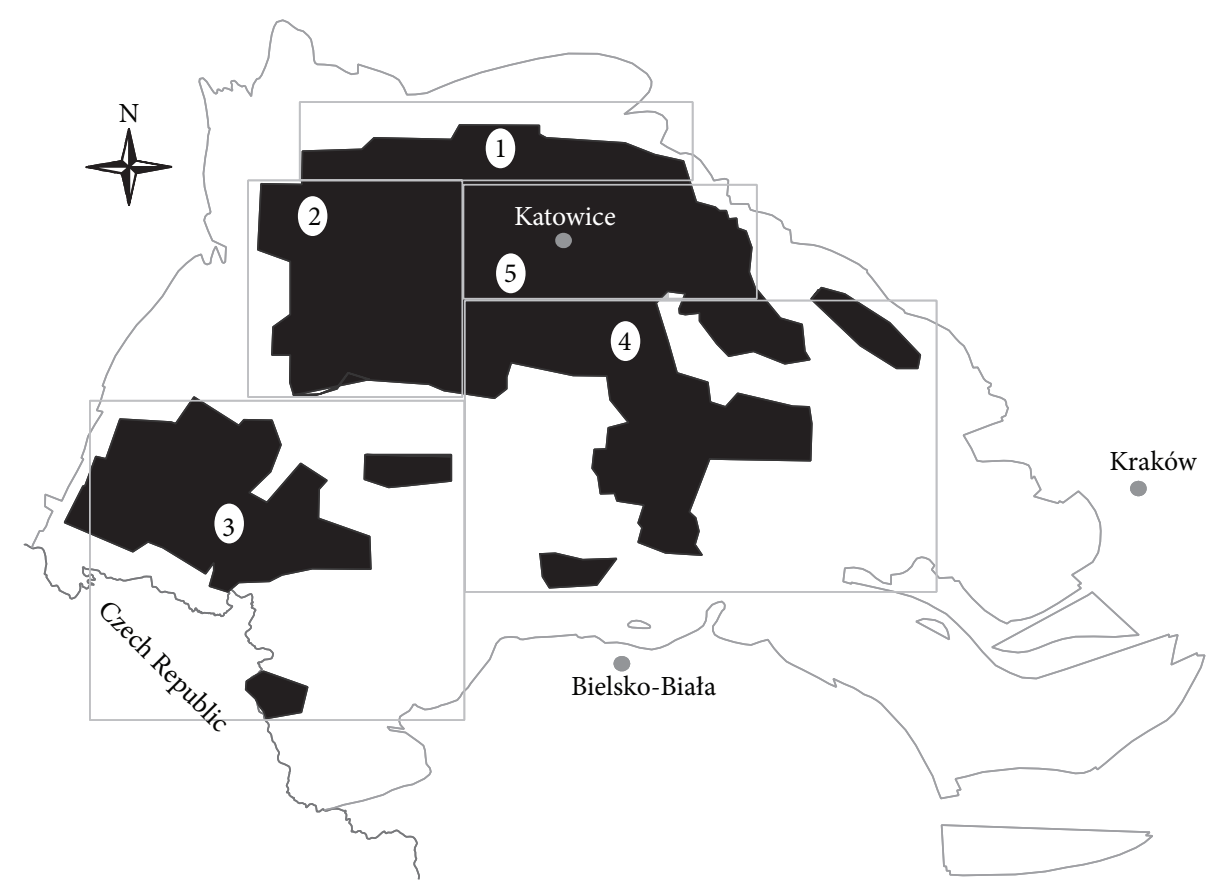

Figure 3: Division of the explored area: 1-north zone, 2-west zone, 3-south zone, 4-east zone, and 5-central zone.

\section{Materials and Methods}

The explored area was divided into five zones (Figure 3), including the following lithostratigraphic members:

(i) northern zone, including paralic series, Upper Silesian sandstone series, and mudstone series with abandoned coal mines,

(ii) western zone, including paralic series with upper marginal beds, Upper Silesian sandstone series with saddle series, and mudstone series with rudzkie and orzeskie coal layers,

(iii) southern zone includes marginal beds (paralic series), Upper Silesian sandstone series, and mudstone series with rudzkie and orzeskie coal layers,

(iv) eastern zone includes Cracow sandstone series with łaziskie and libiąskie coal layers, (v) central zone covers lower part of Cracow sandstone series with łaziskie coal layers, mudstone series, Upper Silesian sandstone series, and paralic series.

Hard coals samples were provided by selected coal mines located in the USCB. 9 samples were taken from coal mines located in the northern zone, 6 samples from the southern zone, 9 samples from the eastern zone, 7 samples from the western zone, and 13 samples from the central zone of the USCB, respectively. The samples were collected in accordance with the standard PN-90/G-04502 from various coal seams. The results of ultimate and proximate analyses as well as the heat of combustion and calorific values of coal samples prepared according to the standard PN-G-04506:1996 are given in Table 2. The samples were analyzed in the accredited Laboratory of Solid Fuels Quality Assessment of the Central Mining Institute, in accordance with the relevant standards in force: PN-G-04511:1980 (total moisture), 
TABLE 2: Values of basic physical and chemical parameters of hard coals of the Upper Silesian Coal Basin (USCB).

\begin{tabular}{|c|c|c|c|c|c|c|c|c|c|}
\hline $\begin{array}{l}\text { Zone of the } \\
\text { USCB }\end{array}$ & $\begin{array}{l}\text { Coal mine } \\
\text { no. }\end{array}$ & $\begin{array}{c}\text { Total } \\
\text { moisture, } W^{a} \\
{[\%]}\end{array}$ & Ash, $A^{a}[\%]$ & $\begin{array}{c}\text { Volatiles, } V^{a} \\
{[\%]}\end{array}$ & $\begin{array}{c}\text { Heat of } \\
\text { combustion, } \\
Q_{s}{ }^{a}[\mathrm{~kJ} / \mathrm{kg}]\end{array}$ & $\begin{array}{c}\text { Calorific } \\
\text { value, } Q_{i}{ }^{a} \\
{[\mathrm{~kJ} / \mathrm{kg}]}\end{array}$ & $\begin{array}{c}\text { Carbon, } \mathrm{C}_{t}{ }^{a} \\
{[\%]}\end{array}$ & $\begin{array}{c}\text { Total sulfur, } \\
\mathrm{S}_{t}{ }^{a}[\%]\end{array}$ & $\begin{array}{c}\text { Pyritic } \\
\text { sulfur, } \mathrm{S}_{\mathrm{p}}{ }^{a} \\
{[\%]}\end{array}$ \\
\hline \multirow{9}{*}{ Northern } & 1 & 5.01 & 15.36 & 28.53 & 28,681 & 23,059 & 64.37 & 0.73 & 0.51 \\
\hline & 2 & 5.81 & 14.14 & 32.13 & 25,663 & 22,989 & 64.12 & 0.82 & 0.44 \\
\hline & 3 & 5.36 & 9.40 & 31.03 & 27,650 & 25,522 & 69.24 & 0.67 & 0.43 \\
\hline & 4 & 4.30 & 15.27 & 29.68 & 26,605 & 24,350 & 67.41 & 0.71 & 0.36 \\
\hline & 5 & 5.13 & 7.52 & 32.72 & 28,522 & 25,720 & 68.32 & 0.88 & 0.41 \\
\hline & 6 & 4.32 & 10.24 & 33.54 & 27,884 & 25,627 & 69.39 & 0.75 & 0.29 \\
\hline & 7 & 2.24 & 7.13 & 31.30 & 30,339 & 28,247 & 75.89 & 0.24 & 0.03 \\
\hline & 8 & 2.44 & 8.22 & 31.14 & 29,954 & 27,738 & 74.23 & 0.53 & 0.13 \\
\hline & 9 & 4.86 & 8.90 & 32.26 & 28,056 & 26,317 & 70.85 & 0.73 & 0.33 \\
\hline \multirow{6}{*}{ Southern } & 10 & 2.35 & 8.07 & 32.05 & 30,101 & 27,954 & 74.53 & 0.62 & 0.08 \\
\hline & 11 & 1.42 & 6.90 & 25.22 & 33,107 & 29,569 & 80.75 & 0.66 & 0.09 \\
\hline & 12 & 1.40 & 15.89 & 29.07 & 25,508 & 26,688 & 69.89 & 0.58 & 0.08 \\
\hline & 13 & 1.74 & 14.42 & 27.76 & 27,350 & 24,339 & 70.62 & 0.59 & 0.08 \\
\hline & 14 & 2.75 & 15.79 & 29.55 & 27,300 & 24,348 & 66.19 & 0.63 & 0.10 \\
\hline & 15 & 2.38 & 14.48 & 29.91 & 28,598 & 25,550 & 68.91 & 0.77 & 0.19 \\
\hline \multirow{9}{*}{ Eastern } & 16 & 11.41 & 15.51 & 31.15 & 22,119 & 17,658 & 55.29 & 2.15 & 1.25 \\
\hline & 17 & 5.74 & 18.86 & 28.86 & 23,425 & 20,734 & 58.19 & 1.20 & 0.60 \\
\hline & 18 & 4.85 & 26.38 & 26.26 & 21,834 & 19,854 & 54.43 & 0.76 & 0.39 \\
\hline & 19 & 5.66 & 21.02 & 28.59 & 23,387 & 19,990 & 56.65 & 1.09 & 0.60 \\
\hline & 20 & 2.80 & 20.25 & 26.51 & 26,503 & 22,889 & 62.16 & 0.64 & 0.24 \\
\hline & 21 & 7.03 & 20.71 & 27.83 & 22,531 & 19,925 & 56.31 & 1.00 & 0.62 \\
\hline & 22 & 2.78 & 25.59 & 25.04 & 23,853 & 21,764 & 59.12 & 0.50 & 0.22 \\
\hline & 23 & 11.97 & 11.72 & 29.76 & 23,298 & 19,109 & 56.69 & 1.92 & 1.41 \\
\hline & 24 & 6.94 & 22.43 & 27.54 & 22,009 & 17,929 & 54.91 & 1.40 & 1.02 \\
\hline \multirow{7}{*}{ Western } & 25 & 1.95 & 18.19 & 26.47 & 27,636 & 23,807 & 67.80 & 0.88 & 0.41 \\
\hline & 26 & 1.79 & 21.21 & 25.91 & 26,330 & 23,508 & 64.66 & 0.74 & 0.32 \\
\hline & 27 & 2.56 & 23.95 & 30.84 & 26,306 & 23,872 & 60.66 & 1.15 & 0.60 \\
\hline & 28 & 1.74 & 19.46 & 27.03 & 27,116 & 24,471 & 65.84 & 1.05 & 0.49 \\
\hline & 29 & 2.44 & 7.84 & 32.63 & 30,616 & 28,510 & 76.25 & 0.89 & 0.56 \\
\hline & 30 & 1.64 & 15.25 & 29.88 & 28,772 & 26,259 & 71.55 & 0.71 & 0.18 \\
\hline & 31 & 1.39 & 11.54 & 30.47 & 30,399 & 28,505 & 75.40 & 0.62 & 0.18 \\
\hline \multirow{13}{*}{ Central } & 32 & 6.72 & 6.20 & 30.83 & 28,094 & 24,246 & 70.91 & 0.61 & 0.40 \\
\hline & 33 & 3.68 & 22.54 & 27.43 & 23,912 & 21,503 & 58.86 & 0.83 & 0.53 \\
\hline & 34 & 3.50 & 17.02 & 33.28 & 26,744 & 23,915 & 64.75 & 0.78 & 0.43 \\
\hline & 35 & 3.32 & 13.83 & 29.35 & 27,932 & 25,439 & 69.00 & 0.56 & 0.32 \\
\hline & 36 & 4.27 & 15.35 & 29.07 & 26,384 & 24,736 & 65.44 & 0.60 & 0.33 \\
\hline & 37 & 3.49 & 11.13 & 29.05 & 28,218 & 24,855 & 70.87 & 0.68 & 0.40 \\
\hline & 38 & 2.67 & 13.30 & 30.27 & 28,302 & 25,492 & 69.34 & 0.39 & 0.16 \\
\hline & 39 & 2.66 & 9.77 & 30.26 & 30,101 & 27,420 & 76.05 & 0.72 & 0.48 \\
\hline & 40 & 2.15 & 8.53 & 28.33 & 31,484 & 29,395 & 77.24 & 0.57 & 0.23 \\
\hline & 41 & 2.85 & 17.56 & 26.93 & 26,992 & 24,534 & 66.82 & 0.79 & 0.28 \\
\hline & 42 & 2.82 & 17.05 & 27.15 & 26,820 & 24,474 & 66.18 & 0.57 & 0.29 \\
\hline & 43 & 3.40 & 7.66 & 31.62 & 29,988 & 27,192 & 74.93 & 0.57 & 0.24 \\
\hline & 44 & 1.90 & 11.04 & 30.64 & 30,229 & 27,635 & 73.60 & 0.67 & 0.35 \\
\hline
\end{tabular}


PN-G-04560:1998 and PN-ISO 1171:2002 (ash), PN-G04516:1998 and PN ISO-562:2000 (volatiles), PN-G04513:1981 (heat of combustion, calorific value), PN-G04584:2001 and PN-ISO 334:1997 (total and pyritic sulfur), and PN-G-04571:1998 (carbon content).

The determination of trace elements was performed in the Department of Environment Engineering of the Central Mining Institute. Coal samples were pretreated before analyses according to the standard ISO 1171:2002. They were combusted in a muffle furnace at $815^{\circ} \mathrm{C}$. Next $3 \mathrm{~g}$ of produced ashes were palletized with graphite. The content of $\mathrm{Hg}$ in samples was determined with a high-temperature combustion technique coupled with cold vapor generation atomic absorption spectrometry (CVAAS) and gold amalgamation method-2000 Nippon Instrument Corporation. The contents of the remaining trace elements were determined with wavelength dispersive X-Ray fluorescence spectrometer Rigaku ZSX Primus.

\section{Results and Discussion}

4.1. Trace Elements Content. The concentrations of trace elements in coal samples of selected zones of the USCB are presented in Table 3. Coal samples of the eastern and the western zones of the USCB are characterized by relatively higher average contents of $\mathrm{Hg}, \mathrm{As}, \mathrm{Cd}, \mathrm{Cr}, \mathrm{Pb}, \mathrm{Rb}, \mathrm{V}$, and $\mathrm{Zn}$ than the remaining coal samples. The highest average concentrations of $\mathrm{As}, \mathrm{Cd}, \mathrm{Pb}$, and $\mathrm{Zn}$ are observed for samples of the western part (15.94, 0.90, 131.57, and 147.52 ppm, resp.), whereas the highest average contents of $\mathrm{Cr}, \mathrm{Rb}$, and $\mathrm{V}$ are reported for coal samples of the eastern zone of the USCB $(26.88,32.86$, and $70.10 \mathrm{ppm}$, resp.).

The geochemical characteristic of the USCB coals indicates that the highest concentrations of $\mathrm{Cr}$ are observed for samples of mudstone series and Upper Silesian sandstone series. The average content of $\mathrm{Cr}$ in Upper Silesian coals is higher than the values reported worldwide (9-13 ppm) [30, 31]. The variations in concentrations of this element in coal seams of particular lithostratigraphic series were insignificant (Table 3).

The average content of $\mathrm{Zn}$ in tested coal samples of USCB (111.19 ppm) is higher than the values reported worldwide $(18-26 \mathrm{ppm})[30,31]$. Concentrations of $\mathrm{Zn}$ in tested coal samples vary across the USCB (from $78.52 \mathrm{ppm}$ in central zone to $147.52 \mathrm{ppm}$ in western zone of the USCB). The highest contents of $\mathrm{Zn}$, locally exceeding $150 \mathrm{ppm}$, are reported for shallowly buried coal seams. The concentrations of $\mathrm{Zn}$ decrease with increasing depth of coal seams in the eastern zone of the USCB, which may be attributed to the postgenetic enrichment of coal in $\mathrm{Zn}$, resulting from the occurrence of $\mathrm{Zn}-\mathrm{Pb}$ ores in the Triassic overburden. The $\mathrm{Zn}$-enrichment of coal seams of the western zone of the USCB may result from the raised geothermal gradient, typical for this region, and magmatism accompanied by various forms of mineralization (Table 3).

The average content of $\mathrm{Pb}$ in coals of the western zone of the USBC (131.57 ppm) is significantly higher than the values reported for the remaining zones (16.58-27.59 ppm) and worldwide (22-28 ppm) [30, 31]. The highest contents of
$\mathrm{Pb}$ are observed for coals sampled from shallowly buried coal seams. The content of $\mathrm{Pb}$ decreases with the depth of coal seams, for example, in coal seams of sandstone series the concentration of $\mathrm{Pb}$ is approximately $77 \mathrm{ppm}$, in mudstone series $57 \mathrm{ppm}$, and in paralic series $39 \mathrm{ppm}$. The Pb-enrichment of coals of the eastern zone of the basin is caused by $\mathrm{Zn}$ and $\mathrm{Pb}$ ores deposited in Triassic formations. The highest contents of $\mathrm{Pb}$ are reported in the western zone of the basin. High concentrations of $\mathrm{Pb}$ are reported for deeper paralic series and low for Upper Silesian sandstone series, which may be attributed to the postgenetic mineralization related to the magmatism.

The average content of $\mathrm{V}$ in tested coal samples (52.34 ppm) is higher than the values reported for world coals (25-35 ppm) [30, 31]. The variations in concentrations of $\mathrm{V}$ for coals of various lithostratigraphic series are insignificant. The lowest values are observed for coal seams of Cracow sandstone series and high values for samples of the western zone of the basin.

Coal samples of the western zone of the USCB are also characterized by the highest average concentrations of $\mathrm{Ba}$ and $\mathrm{Ni}$ (386.30 and $28.34 \mathrm{ppm}$ ), whereas coal samples of the eastern zone of the USCB are unique due to the highest average content of $\mathrm{Mn}$ (157.69 ppm). The highest average $\mathrm{Hg}$ content is observed for coal samples of the eastern and the western zones of the USCB (0.03 ppm) (Table 3$)$.

The lowest average contents of $\mathrm{Ba}, \mathrm{Co}, \mathrm{Cr}, \mathrm{Cu}, \mathrm{Ni}, \mathrm{Rb}, \mathrm{Sr}$, and $\mathrm{V}(142.66,5.44,10.73,17.47,12.14,8.04,121.51$, and 25.24 ppm) are observed for coal samples of the northern zone, whereas the lowest contents of $\mathrm{Hg}$ and $\mathrm{Mn}$ (0.01 and 69.37 ppm, resp.) are reported for coal samples of the southern zone of the USCB (Table 3).

Concentration of $\mathrm{Ba}$ in coal samples shows significant lateral variations resulting from the geological conditions. The average content of $\mathrm{Ba}$ in coal samples (257.10 ppm; Table 3) is higher than the values reported for world coals (111-149 ppm) [30, 31]. The highest concentrations of $\mathrm{Ba}$ are reported for coal seams of the western zone of the basin $(386.30 \mathrm{ppm})$, in particular for coal seams located close to large and deep sinks filled with Miocene formations of saline sediments and evaporites. Barite veins are observed in coal seams of coal mines located in this area of the basin as well as deposition of barite from mine water.

The average concentration of $\mathrm{Ni}$ in coal samples is $21.21 \mathrm{ppm}$, which is slightly higher than the values reported worldwide (14-18 ppm) [30, 31]. The highest contents of $\mathrm{Ni}$ are observed for coals of mudstone series and Upper Silesian sandstone series and the lowest for samples of Cracow sandstone series (Table 3 ).

The average content of $\mathrm{Mn}$ in tested coal samples of the USCB amounts to $116.97 \mathrm{ppm}$ (Table 3) and is higher than the values reported worldwide $(79-111 \mathrm{ppm})$ [30, 31]. The lowest average concentration of this element is reported for coal seams of Cracow sandstone series, medium for coals of mudstone series and Upper Silesian sandstone series, and the highest for coals of paralic series. Significant enrichments of coals in $\mathrm{Fe}\left(60-70 \% \mathrm{Fe}_{2} \mathrm{O}_{3}\right.$ in ash) are observed locally within the paralic series, often accompanied by high concentration of $\mathrm{Mn}$ (this concerns mainly nonpyritic iron). 


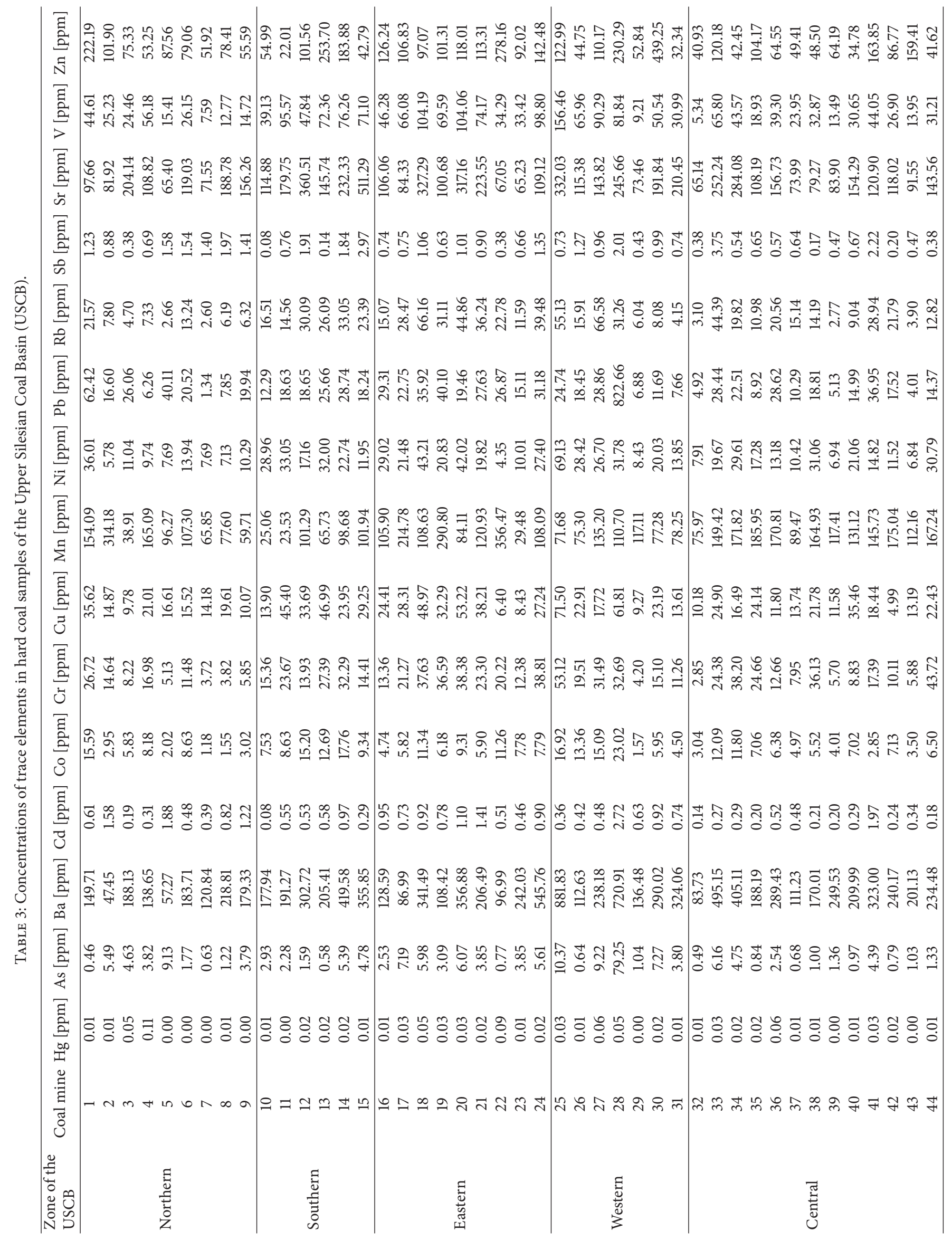


Coal samples provided by coal mines located in southern and western zones of the USCB are characterized by high average concentration of $\mathrm{Sb}(1.28$ and $1.23 \mathrm{ppm}$, resp.). Furthermore, the highest average contents of $\mathrm{Co}, \mathrm{Cu}$, and $\mathrm{Sr}$ are observed for samples of the southern zone of the USCB (11.86, 32.20 and $257.42 \mathrm{ppm}$, resp.) (Table 3).

The uniqueness of coal samples collected in the central zone of the USCB was attributed to the lowest average concentrations of $\mathrm{As}, \mathrm{Cd}, \mathrm{Pb}, \mathrm{Sb}$, and $\mathrm{Zn}$ (2.03, 0.41, 16.58, 0.85 , and $78.52 \mathrm{ppm}$, resp.) among the analyzed samples.

The average content of $\mathrm{Co}$ in tested coal samples is $8.57 \mathrm{ppm}$, which is higher than the values reported worldwide $(4.9-5.5 \mathrm{ppm})[30,31]$. The variations in content of Co between coals of various lithostratigraphic series are not significant. High concentrations of $\mathrm{Co}$ are observed for coals of the southern and western zones of the USCB, and the lowest concentrations are observed for samples of the northern and central zones coal seams (Table 3).

The average content of $\mathrm{Cu}$ in Upper Silesian coals (25.69 ppm) is similar to the values reported for world coals $(16-20 \mathrm{ppm})[30,31]$. The highest content of this element is reported for coal seams of Upper Silesian sandstone series and the lowest for Cracow sandstone series (Table 3). Slight $\mathrm{Cu}$-enrichment is observed for coal seams of the southwestern zone of the USCB, similar to the case of $\mathrm{Zn}$ and $\mathrm{Pb}$. The average $\mathrm{Cu}$ content in coals of the southern zone increases with increasing depth of coal seams and amounts to 23 ppm for mudstone series, 41 ppm for Upper Silesian sandstone series, and $92 \mathrm{ppm}$ for paralic series. The mechanism of the $\mathrm{Cu}$-enrichment is probably similar to the one proposed for $\mathrm{Zn}$ - and $\mathrm{Pb}$-enrichment.

4.2. Hierarchical Clustering Analysis. Coal samples provided by coal mines located in particular zones of the USCB differed both in terms of basic physical and chemical parameters and the contents of trace elements. The hierarchical clustering analysis (HCA) was applied to investigate the similarities and dissimilarities between the tested samples $[20-26,32]$. The analyzed data set was organized in a matrix $\mathbf{X}(44 \times 23)$. The rows of the matrix represent the tested coal samples provided by coal mines located in various zones of the USCB, whereas columns represent 23 parameters, including basic physical and chemical parameters and contents of trace elements (see Table 4). The data set was standardized since the measured parameters differed significantly in their ranges:

$$
x_{i j}=\frac{x_{i j}-\bar{x}_{j}}{s_{j}},
$$

where $\bar{x}_{j}, s_{j}$ denote the mean of the $j$ th column and its standard deviation, respectively.

The HCA helped reveal the internal data structure and thereof its clustering tendency. It enabled the analysis of the data structure by tracing the similarities/dissimilarities between objects (hard coal samples) in the parameters space and parameters in the objects space. The results were presented in a form of dendrograms, of which $O X$ axis showed the sequence of objects/parameters clustering and $O Y$ axis determined the similarity/dissimilarity between them.
TABLE 4: Parameters of hard coal samples of the Upper Silesian Coal Basin (USCB) analyzed with HCA.

\begin{tabular}{|c|c|c|}
\hline No. & Parameter & Unit \\
\hline 1 & Total moisture, $W^{a}$ & [\%] \\
\hline 2 & Ash, $A^{a}$ & {$[\%]$} \\
\hline 3 & Volatiles, $V^{a}$ & {$[\%]$} \\
\hline 4 & Total sulfur, $\mathrm{S}_{t}{ }^{a}$ & {$[\%]$} \\
\hline 5 & Heat of combustion, $Q_{s}{ }^{a}$ & {$[\mathrm{~kJ} / \mathrm{kg}]$} \\
\hline 6 & Calorific value, $Q_{i}{ }^{a}$ & {$[\mathrm{~kJ} / \mathrm{kg}]$} \\
\hline 7 & Carbon, $\mathrm{C}_{t}{ }^{a}$ & {$[\%]$} \\
\hline 8 & Pyritic sulfur, $\mathrm{S}_{\mathrm{p}}{ }^{a}$ & {$[\%]$} \\
\hline 9 & $\mathrm{Hg}$ & [ppm] \\
\hline 10 & As & {$[\mathrm{ppm}]$} \\
\hline 11 & $\mathrm{Ba}$ & [ppm] \\
\hline 12 & $\mathrm{Cd}$ & [ppm] \\
\hline 13 & Co & [ppm] \\
\hline 14 & $\mathrm{Cr}$ & [ppm] \\
\hline 15 & $\mathrm{Cu}$ & {$[\mathrm{ppm}]$} \\
\hline 16 & $\mathrm{Mn}$ & [ppm] \\
\hline 17 & $\mathrm{Ni}$ & {$[\mathrm{ppm}]$} \\
\hline 18 & $\mathrm{~Pb}$ & [ppm] \\
\hline 19 & $\mathrm{Rb}$ & [ppm] \\
\hline 20 & $\mathrm{Sb}$ & [ppm] \\
\hline 21 & $\mathrm{Sr}$ & [ppm] \\
\hline 22 & $\mathrm{~V}$ & [ppm] \\
\hline 23 & $\mathrm{Zn}$ & [ppm] \\
\hline
\end{tabular}

The HCA methods differ in terms of parameters similarity measure applied and ways of cluster linking. The results presented in the paper were based on the Euclidean distance and the Ward linkage algorithm (see Figure 4). The Ward linkage method was based on the inner squared distance of clusters, so that at each stage these two clusters were merged, for which the minimum increase in the total withingroup error sums of squares was observed. The dendrogram revealed the data structure (i.e., the subgroups of hard coal samples), but it allowed no interpretation of the observed patterns in terms of the parameters. To solve this problem a color map of the experimental standardized data sorted according to the order of objects and parameters observed on the dendrograms was used [32]. Simultaneous interpretation of the dendrogram of objects with the color map of the experimental data allowed more in-depth analysis of the relationships between hard coal samples from various zones of the USCB and measured parameters.

The dendrogram presented in Figure 4(a) enabled to distinguish three clusters: $\mathrm{A}, \mathrm{B}$, and $\mathrm{C}$ and one nonclustered object no. 28. Cluster A grouped six coal samples provided by coal mines located in the northern zone of the USCB (objects nos. 3, 5-9), one sample of the western zone (objet no. 29) and four samples of the central zone of the USCB (objects nos. 32, 37, 39, and 43, resp.). In cluster B, all samples of the southern zone (objects nos. 10-15), the remaining samples of the northern zone (objects nos. 1,2, and 4), one sample of the eastern zone (object no. 22), two samples of the western zone 


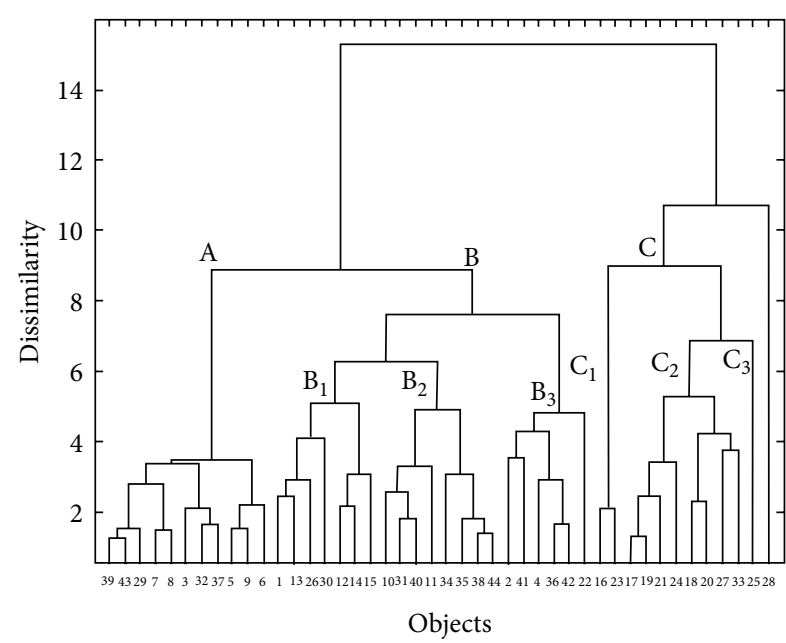

(a)

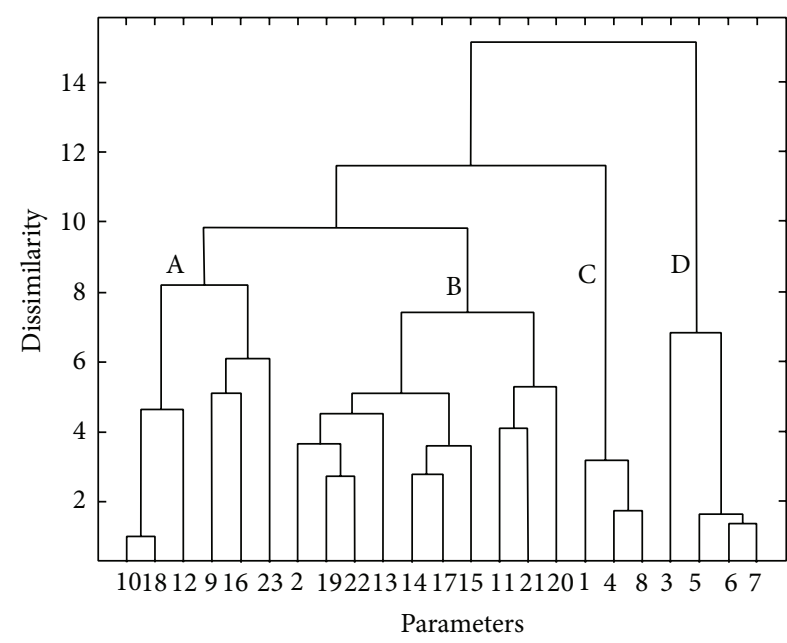

(b)

Figure 4: Dendrograms of (a) hard coal samples (objects) in the space of the 23 measured parameters (listed in Table 4) and (b) parameters in the space of 44 objects based on the Ward linkage method using Euclidean distance as the similarity measure.

(objects nos. 30 and 31), and the remaining samples of the central zone (except for sample no. 33) (objects nos, 34-36, $38,40-42$, and 44) were collected. Cluster $C$ was composed of samples of the eastern zone (objects nos. 16-21, 23, and 24), two samples of the western zone (objects nos. 25 and 27), and one sample of the central zone of the USCB (object no. 33). In the main clusters $B$ and $C$, additional substructures were distinguished. Namely, in cluster B, the following three subclusters of objects were observed:

(i) subcluster B1: collecting one sample of the northern zone (object no. 1), four samples of the southern (objects nos. 12-15), and two samples of the western zones of the USCB (objects nos. 26 and 30),

(ii) subcluster B2: composed of two samples of the southern zone (objects nos. 10 and 11), one sample of the western zone (object no. 31), and five samples of the central zone of the USCB (objects nos. 34, 35, 38, 40, and 44), and

(iii) subcluster B3: including two samples of the northern zone (objects nos. 2 and 4 ), one sample of the eastern zone (object no. 22), and three samples of the central zone of the USCB (objects nos. 36, 41, and 42, resp.).

In cluster $\mathrm{C}$ three subclusters $(\mathrm{C} 1, \mathrm{C} 2$, and $\mathrm{C} 3)$ were distinguished. Subcluster $\mathrm{C} 1$ included two samples of the eastern zone of the USCB (objects nos. 16 and 23),,subcluster C2 included six samples of the eastern zone (objects nos. 17-21 and 24) and one sample of the western and central zones (objects nos. 27 and 33, resp.), and subcluster C3 was composed of one sample of the western zone of the USCB (object no. 25).

The dendrogram constructed for the basic physical and chemical parameters and trace elements contents (see Figure 4(b)) revealed four main groups: (i) group A: including parameters nos. 9, 10,12,16,18, and 23, which represent the contents of $\mathrm{Hg}, \mathrm{As}, \mathrm{Cd}, \mathrm{Mn}$, $\mathrm{Pb}$, and $\mathrm{Zn}$, respectively,

(ii) group B collecting parameters nos. 2, 11, 13-15, 17, and 19-22, which represent the contents of ash, $\mathrm{Ba}, \mathrm{Co}, \mathrm{Cr}$, $\mathrm{Cu}, \mathrm{Ni}, \mathrm{Rb}, \mathrm{Sb}, \mathrm{Sr}$, and $\mathrm{V}$, respectively,

(iii) group C, composed of parameters nos. 1, 4, and 8 , which represent contents of total moisture, total sulfur, and pyritic sulfur, respectively, and

(iv) group D, including parameters nos. 3 and 5-7, which represent contents of volatiles, heat of combustion, calorific value, and carbon content, respectively.

The dendrogram of hard coal samples of various zones of the USCB presented the data structure but did not allow investigation of the observed patterns in terms of the original parameters. This disadvantage was overcome with the use of the color map of the standardized experimental data, sorted according to the specific order of objects (hard coal samples) and parameters adopted from the above described dendrograms [32].

The analysis of the dendrogram of 44 objects in the space of the 23 parameters sorted according to the Ward linkage method with the data color map allowed more in-depth investigation of the resulting clustering tree (see Figure 5).

Coal samples collected in cluster A were characterized by the lowest contents of $\mathrm{Co}, \mathrm{Cr}, \mathrm{Rb}$, and $\mathrm{V}$ (parameters nos. 13,14, 19, and 22), low contents of ash, $\mathrm{Cu}$, and $\mathrm{Ni}$ (parameters nos. 2, 15, and 17), and higher content of volatiles (parameter no. 3) than the remaining coal samples. Furthermore, the uniqueness of samples of northern, western, and central zones of the USCB (objects nos. 7, 8, 29, 39, and 43) was observed, resulting from high heat of combustion, calorific values, and carbon content (parameters nos. 5-7). 


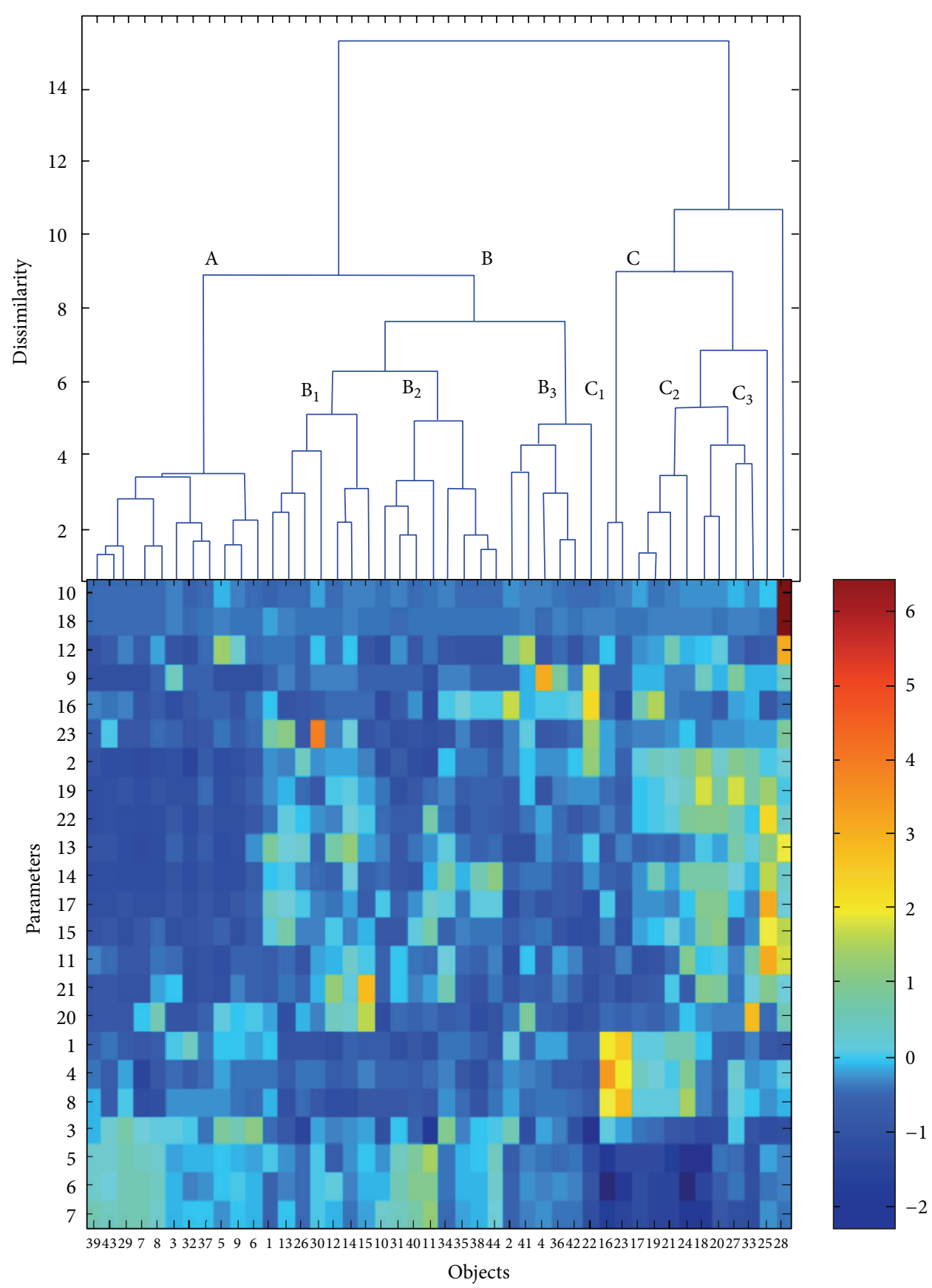

FIGURE 5: Dendrogram of 44 hard coal samples from various coal mines of the USCB (objects) in the space of the 23 measured parameters with the color map of the studied data sorted according to the Ward linkage method.

Furthermore, one sample of the northern zone of the USCB (object no. 5) was characterized by the highest content of $\mathrm{Cd}$ (parameter no. 12).

All coal samples grouped in cluster B differed from the remaining tested samples mainly due to relatively low contents of total moisture, pyritic sulfur, and total sulfur (parameters nos. 1,8 , and 4 ).

Subcluster B1 was characterized by relatively high Co content (parameter no. 13), subcluster B2 by the lowest $\mathrm{Zn}$ content (parameter no. 23) and high heat of combustion, calorific value, and content of carbon (parameters nos. 5,
6, and 7), whereas subcluster B3 was unique due to high contents of $\mathrm{Hg}$ and $\mathrm{Mn}$ (parameters nos. 9 and 16). Coal samples of the southern and western zones of the USCB (objects nos. 15 and 30) were unique because of the highest contents of $\mathrm{Sr}$ and $\mathrm{Zn}$ (parameters nos. 21 and 23, respectively). Furthermore, coal samples of the northern and eastern zones (objects nos. 4 and 22) differed from the remaining samples due to the highest content of $\mathrm{Hg}$ (parameter no. 9). Moreover, the coal sample of the eastern zone of the USCB (object no. 22) was characterized by high contents of ash, $\mathrm{Mn}$, and $\mathrm{Zn}$ (parameters nos. 2, 16, and 23, resp.). 
The samples of cluster $\mathrm{C}$, collecting samples of the eastern (objects nos. 16-21, 23, and 24), western (objects nos. 25 and 27), and central (object no. 33) zones of the USCB differed from the remaining samples due to the highest contents of ash, Cr, Rb, and V (parameters nos. 2, 14, 19, and 22) and relatively low values of volatiles, heat of combustion, calorific value, and carbon content (parameters nos. 3 and 5-7, resp.). Furthermore, the samples of the eastern zone (objects nos. 16 and 23) collected in subcluster $\mathrm{Cl}$ were characterized by the highest contents of total moisture, total sulfur, and pyritic sulfur (parameters nos. 1, 4, and 8). Coal samples of the eastern, western, and central zones (objects nos. 17-21, 24, 27, and 33, resp.), grouped in subcluster C2 were characterized by high contents of ash and $\mathrm{Rb}$ (parameters nos. 2 and 19), whereas the uniqueness of one sample of the western zone (object no. 25-see subcluster C3) resulted from the highest contents of $\mathrm{Ba}, \mathrm{Cr}, \mathrm{Cu}, \mathrm{Ni}$, and $\mathrm{V}$ (parameters nos. 11, 14, 15, 17 , and 22) among all the tested samples.

The uniqueness of the nonclustered sample of the western zone of the USCB (object no. 28) was caused by the extremely high contents of $\mathrm{As}, \mathrm{Cd}$, and $\mathrm{Pb}$ (parameters nos. 10, 12, and 18) and low contents of total moisture and volatiles (parameters nos. 1 and 3 ) in comparison with the remaining samples.

\section{Conclusions}

The detailed analysis of the average trace elements concentrations in the tested coal samples of the northern, southern, western, eastern, and central zones of the USCB allowed us to draw the following conclusions.

(1) Coal samples of the eastern and western zones of the USCB were characterized by high average contents of $\mathrm{Hg}$, As, $\mathrm{Cd}, \mathrm{Cr}, \mathrm{Pb}, \mathrm{Rb}, \mathrm{V}$, and $\mathrm{Zn}$. The highest average concentrations of $\mathrm{As}, \mathrm{Cd}, \mathrm{Pb}$, and $\mathrm{Zn}$ were observed for samples of the western zone of the USCB.

The average content of $\mathrm{Zn}$ in tested coal samples of the USCB was higher than the values reported worldwide. $\mathrm{Zn}$ content varied across the USCB and decreased with increasing depth of coal seams in the eastern zone of the USCB, which may be attributed to the postgenetic enrichment of coal in $\mathrm{Zn}$, resulting from the occurrence of $\mathrm{Zn}-\mathrm{Pb}$ ores in the Triassic overburden. The Zn-enriched coal seams of the western zone of the USCB may result from the raised geothermal gradient, magmatism accompanied, and various forms of mineralization.

The average content of $\mathrm{Pb}$ in coals of the western zone of the USBC was significantly higher than the values reported for the remaining zones and worldwide. The content of $\mathrm{Pb}$ decreased with the depth of coal seams. The Pb-enrichment of coals of the eastern zone of the basin may result from the deposition of $\mathrm{Zn}$ and $\mathrm{Pb}$ ores in Triassic formations. High concentrations of $\mathrm{Pb}$ were reported for deeper paralic series and low concentrations were reported for Upper Silesian sandstone series, which may be attributed to the postgenetic mineralization related to the magmatism.

(2) The highest average concentrations of $\mathrm{Cr}, \mathrm{Rb}$, and $\mathrm{V}$ were reported for coal samples of the eastern zone. The average content of $\mathrm{Cd}$ in tested samples was lower and of $\mathrm{Cr}$ was higher than the values reported worldwide. The variations in the concentration of these elements in coal seams of particular lithostratigraphic series were insignificant. The average content of $\mathrm{V}$ in tested coal samples was higher than the values reported for world coals. The variations in concentrations of $\mathrm{V}$ for coals of various lithostratigraphic series were insignificant. The lowest values were observed for coal seams of Cracow sandstone series and high values for samples of the western zone of the basin.

(3) The highest average concentrations of $\mathrm{Ba}$ and $\mathrm{Ni}$ were observed for coals of the western zone. Concentration of $\mathrm{Ba}$ in coal samples tested showed significant lateral variations resulting from the geological conditions. The average content of $\mathrm{Ba}$ in tested coal samples was higher than the values reported for world coals. The highest concentrations of $\mathrm{Ba}$ were reported for the area, where barite veins are observed in coal seams as well as deposition of barite from mine water. The average concentration of $\mathrm{Ni}$ in tested coal samples was slightly higher than the values reported worldwide.

(4) Coal samples of the northern zone of the USCB were characterized by the lowest average $\mathrm{Ba}, \mathrm{Co}, \mathrm{Cr}, \mathrm{Cu}, \mathrm{Ni}, \mathrm{Rb}$, $\mathrm{Sr}$, and $\mathrm{V}$ contents. The average content of Co in tested coal samples was higher than the values reported worldwide. The differences in content of Co between coals seams of various lithostratigraphic series were not significant. The average content of $\mathrm{Cu}$ in Upper Silesian coals was similar to the values reported for world coals. Slight $\mathrm{Cu}$-enrichment was observed for coal seams of the south-western zone of the USCB. The average $\mathrm{Cu}$ content in coals of the southern zone increased with increasing depth of coal seams and the mechanism of the $\mathrm{Cu}$-enrichment was probably similar to the one proposed for $\mathrm{Zn}$ and $\mathrm{Pb}$.

(5) Coal samples of the southern zone of the USCB were characterized by the lowest contents of $\mathrm{Hg}$ and $\mathrm{Mn}$. The average content of $\mathrm{Mn}$ in tested coal samples was higher than the values reported worldwide. Significant enrichments of coals in Fe were observed locally within the paralic series, often accompanied by high concentration of $\mathrm{Mn}$.

(6) The lowest average concentrations of $\mathrm{As}, \mathrm{Cd}, \mathrm{Pb}, \mathrm{Sb}$, and $\mathrm{Zn}$ were observed for coal samples collected in the central zone of the USCB.

\section{Conflict of Interests}

The authors declare that there is no conflict of interests regarding the publication of this paper.

\section{Acknowledgment}

The works presented in the paper have been performed within the Project no. 11320322-380 supported by the Polish Ministry of Science and Higher Education.

\section{References}

[1] A. Smoliński, "Coal char reactivity as a fuel selection criterion for coal-based hydrogen-rich gas production in the process of steam gasification," Energy Conversion and Management, vol. 52, no. 1, pp. 37-45, 2011. 
[2] Polish Geological Institute (PIG), http://www.pgi.gov.pl/.

[3] A. Franco and A. R. Diaz, "The future challenges for "clean coal technologies": joining efficiency increase and pollutant emission control," Energy, vol. 34, no. 3, pp. 348-354, 2009.

[4] D. J. Swaine, "Why trace elements are important," Fuel Processing Technology, vol. 65-66, pp. 21-33, 2000.

[5] W. Wang, Y. Qin, J. Wang, J. Li, and D. J. Weiss, "A preliminary method for determining acceptable trace element levels in coal," Energy, vol. 35, no. 1, pp. 70-76, 2010.

[6] B. M. Gibbs, D. Thompson, and B. B. Argent, "Mobilisation of trace elements from as-supplied and additionally cleaned coal: pedictions for $\mathrm{Ba}, \mathrm{Be}, \mathrm{Cd}, \mathrm{Co}, \mathrm{Mo}, \mathrm{Nb}, \mathrm{Sb}, \mathrm{V}$ and W,' Fuel, vol. 87, no. 7, pp. 1217-1229, 2008.

[7] F. Goodarzi, "Assessment of elemental content of milled coal, combustion residues, and stack emitted materials: possible environmental effects for a Canadian pulverized coal-fired power plant," International Journal of Coal Geology, vol. 65, no. 1-2, pp. 17-25, 2006.

[8] F. Goodarzi, F. E. Huggins, and H. Sanei, "Assessment of elements, speciation of As, $\mathrm{Cr}, \mathrm{Ni}$ and emitted $\mathrm{Hg}$ for a Canadian power plant burning bituminous coal," International Journal of Coal Geology, vol. 74, no. 1, pp. 1-12, 2008.

[9] M. L. Johnson, H.-Y. Lai, and D. Wortman, "Preventing mercury emissions from coal-fired power plants using environmentally preferable coal purchasing practices," Journal of Cleaner Production, vol. 16, no. 6, pp. 716-721, 2008.

[10] L. Y. Kizilshtein and Y. I. Kholodkov, "Ecologically hazardous elements in coals of the Donets Basin," International Journal of Coal Geology, vol. 40, no. 2-3, pp. 189-197, 1999.

[11] Z. Li, A. H. Clemens, T. A. Moore, D. Gong, S. D. Weaver, and N. Eby, "Partitioning behaviour of trace elements in a stoker-fired combustion unit: an example using bituminous coals from the Greymouth coalfield (Cretaceous), New Zealand," International Journal of Coal Geology, vol. 63, no. 1-2, pp. 98-116, 2005.

[12] Y. E. Yudovich and M. P. Ketris, "Arsenic in coal: a review," International Journal of Coal Geology, vol. 61, no. 3-4, pp. 141196, 2005.

[13] L. Zhang, Y. Zhuo, L. Chen, X. Xu, and C. Chen, "Mercury emissions from six coal-fired power plants in China," Fuel Processing Technology, vol. 89, no. 11, pp. 1033-1040, 2008.

[14] J. Wang, O. Yamada, T. Nakazato, Z.-G. Zhang, Y. Suzuki, and K. Sakanishi, "Statistical analysis of the concentrations of trace elements in a wide diversity of coals and its implications for understanding elemental modes of occurrence," Fuel, vol. 87, no. 10-11, pp. 2211-2222, 2008.

[15] F. Vejahati, Z. Xu, and R. Gupta, "Trace elements in coal: associations with coal and minerals and their behavior during coal utilization-a review," Fuel, vol. 89, no. 4, pp. 904-911, 2010.

[16] G. Liu, Z. Peng, P. Yang, H. Gui, and G. Wang, "Characteristics of coal ashes in Yanzhou mining district and distribution of trace elements in them," Chinese Journal of Geochemistry, vol. 20, no. 4, pp. 357-367, 2001.

[17] A. Iwashita, S. Tanamachi, T. Nakajima, H. Takanashi, and A. Ohki, "Removal of mercury from coal by mild pyrolysis and leaching behavior of mercury," Fuel, vol. 83, no. 6, pp. 631-638, 2004.

[18] Y. Sekine, K. Sakajiri, E. Kikuchi, and M. Matsukata, "Release behavior of trace elements from coal during high-temperature processing," Powder Technology, vol. 180, no. 1-2, pp. 210-215, 2008.
[19] R. Guo, J. Yang, and Z. Liu, "Behavior of trace elements during pyrolysis of coal in a simulated drop-tube reactor," Fuel, vol. 83, no. 6, pp. 639-643, 2004.

[20] L. Kaufman and P. J. Rousseeuw, Finding Groups in Data: An Introduction to Cluster Analysis, John Wiley \& Sons, New York, NY, USA, 1990.

[21] D. L. Massart and L. Kaufman, The Interpretation of Analytical Data by the Use of Cluster Analysis, John Wiley \& Sons, New York, NY, USA, 1983.

[22] H. C. Romesburg, Cluster Analysis for Researchers, Lifetime Learning Publications, Belmont, Calif, USA, 1984.

[23] J. Wang, Y.-T. Cao, J.-Y. Xie, and S.-F. Chen, "Energy efficient backoff hierarchical clustering algorithms for multi-hop wireless sensor networks," Journal of Computer Science and Technology, vol. 26, no. 2, pp. 283-291, 2011.

[24] J. H. Ward, "Hierarchical grouping to optimize an objective function," Journal of the American Statistical Association, vol. 58, no. 301, pp. 236-244, 1963.

[25] B. G. M. Vandeginste, D. L. Massart, L. M. C. Buydens, S. de Jong, P. J. Lewi, and J. Smeyers-Verbeke, Handbook of Chemometrics and Qualimetrics: Part B, Elsevier, Amsterdam, The Netherlands, 1998.

[26] W. Vogt, D. Nagel, and H. Sator, Cluster Analysis in Clinical Chemistry: A Model, John Wiley \& Sons, New York, NY, USA, 1987.

[27] J. Jureczka and A. Kotas, "Coal deposits-Upper Silesian Coal Basin," in The Carboniferous System in Poland, H. Żakowa and A. Zdanowski, Eds., pp. 164-173, Papers of the Polish Geological Institute, Warsaw, Poland, 1995.

[28] J. Jureczka, W. Krieger, and S. Wilk, "Zasoby perspektywiczne węgla kamiennego w Górnośląskim Zagłębiu Węglowym," in Proceedings of the 19th Konferencja $z$ Cyklu "Aktualia $i$ Perspektywy Gospodarki Surowcami Mineralnymi”, PAN Instytut Gospodarki Surowcami Mineralnymi i Energią, Kraków, Poland, 2009.

[29] M. Nieć, Hard Coal and Anthracite Deposits in Poland. Energy Resources: Hard Coal, Lignite, Mineral Resources of Poland, CPPGSMiE PAN, Cracow, Poland, 1996.

[30] B. Ptak and A. Różkowska, Geochemical Atlas of the USCB Coal Deposits, Polish Geological Institute, Warsaw, Poland, 1995, (Polish).

[31] J. E. Judowicz, M. P. Ketris, and A. W. Mierc, Elementy-Primiesi w Iskopajemych Ugljach, Nauka, Moscow, Russia, 1985.

[32] A. Smoliński, B. Walczak, and J. W. Einax, "Hierarchical clustering extended with visual complements of environmental data set," Chemometrics and Intelligent Laboratory Systems, vol. 64, no. 1, pp. 45-54, 2002.

[33] W. Gabzdyl, Geology of Deposits, The Publishing House of the Silesian University of Technology, Gliwice, Poland, 1999, (Polish). 

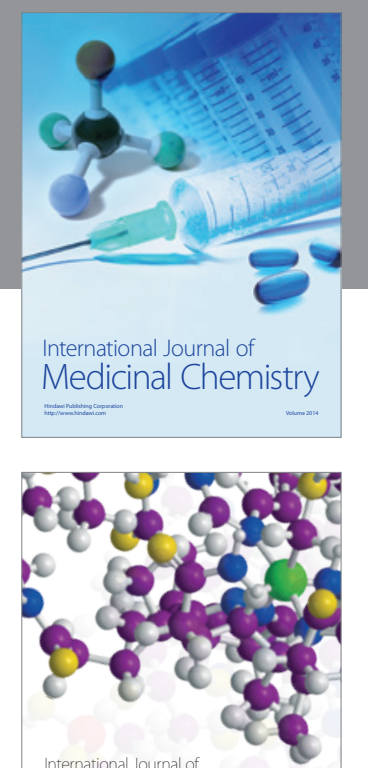

\section{Carbohydrate} Chemistry

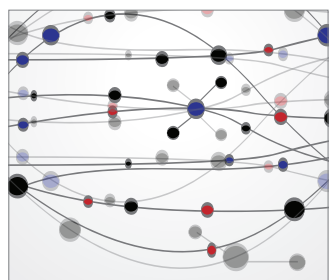

The Scientific World Journal
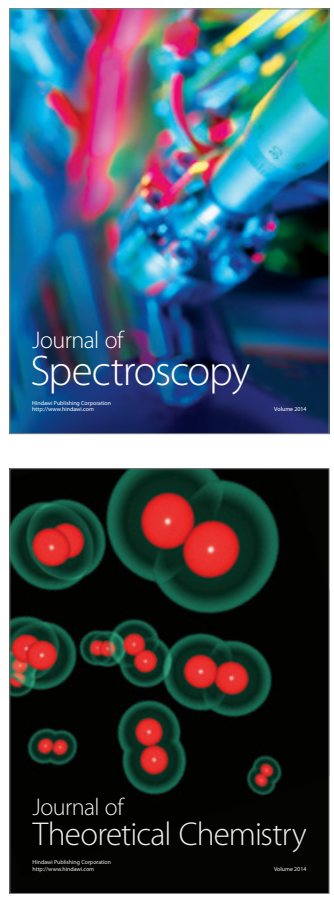
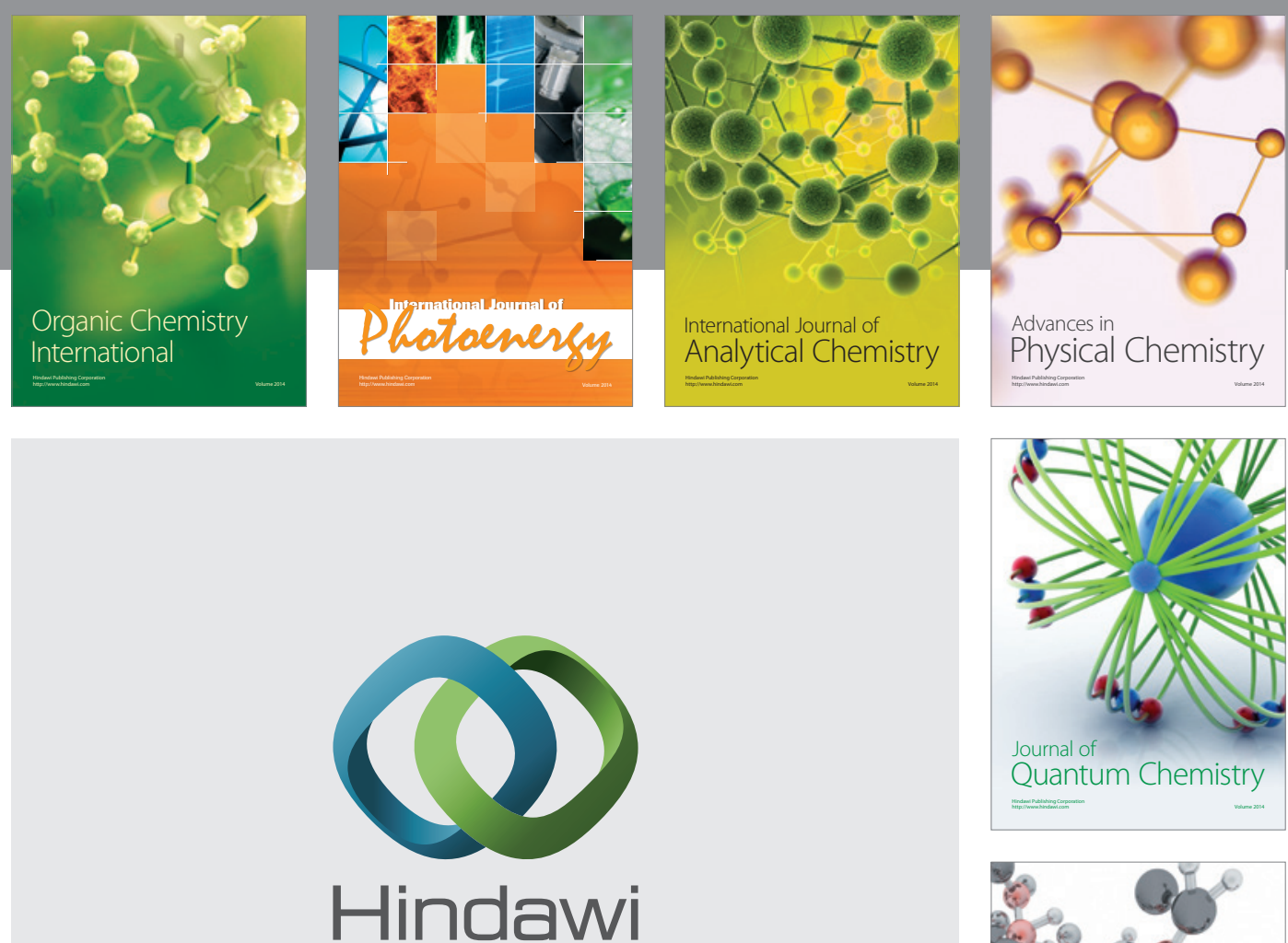

Submit your manuscripts at

http://www.hindawi.com

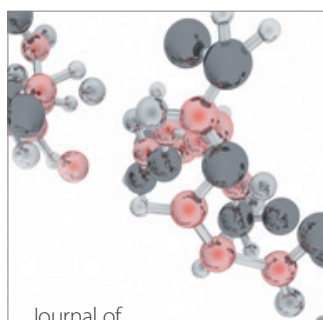

Analytical Methods

in Chemistry

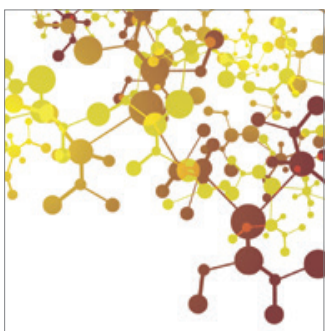

Journal of

Applied Chemistry

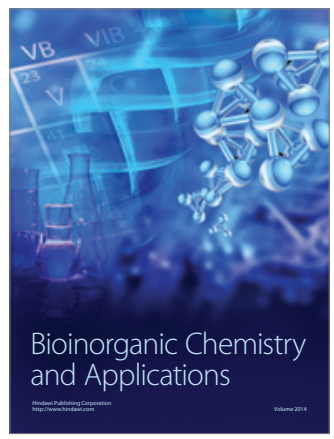

Inorganic Chemistry
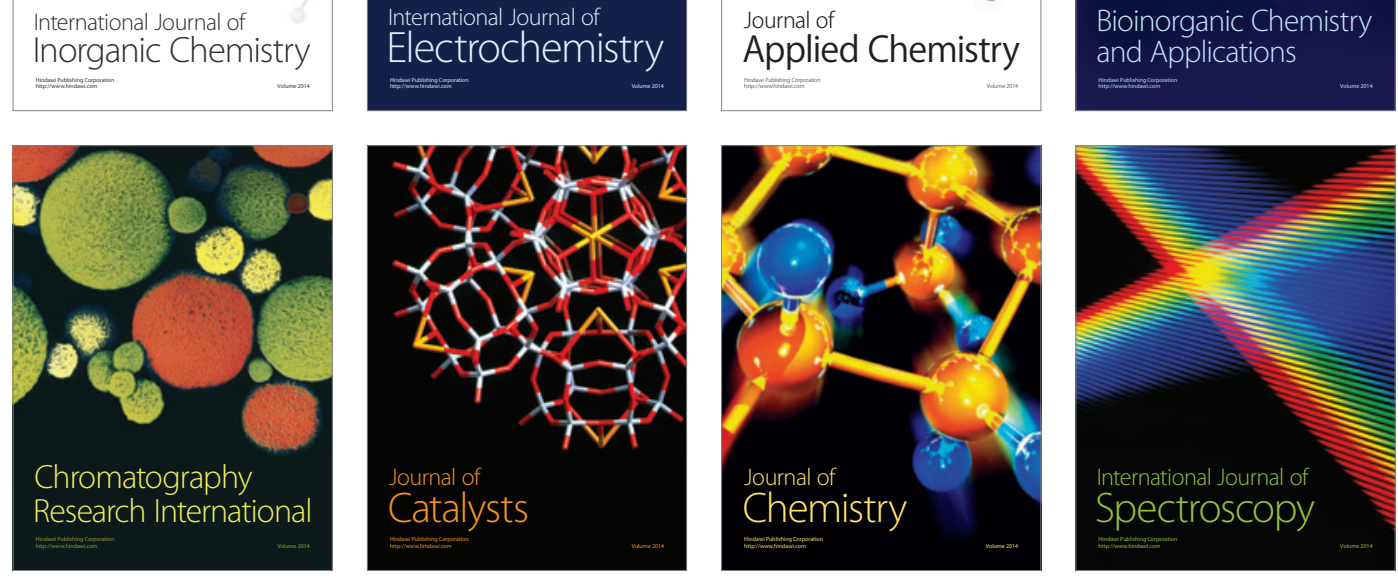